\title{
Olasılık: Janus Yüzlülügüun Eski ve Yeni Görünümleri
}

\section{Doc. Dr. Adil Korkmaz ${ }^{1 *}$ Ayşenur Avar ${ }^{2}$}

Geliș tarihi: 29.12.2018

Kabul tarihi: 29.01.2019

\section{Atıf bilgisi:}

Uluslararası Bilimsel

Araștırmalar Dergisi (IBAD)

Cilt: $4 \quad$ Sayı: 1

Sayfa: 81-92 Yıl: 2019

Dönem: Kış

This article was checked by iThenticate Similarity Index $02 \%$

${ }^{1}$ Akdeniz Üniversitesi, Türkiye, adilkorkmaz@akdeniz.edu.tr,

\section{ORCID ID 0000-0002-2432-518X}

2 Akdeniz Üniversitesi, Türkiye, aysenuravar@gmail.com,

ORCID ID 0000-0002-6657-3552

* Sorumlu yazar

\section{ÖZ}

Olasılık, bir yüzüyle geçmișe, öbür yüzüyle geleceğe bakan Roma tanrısı Janus'a benzetilir. Böyle bir tutumun nedeni olasılığın bir yandan nesnel, öbür yandan öznel gerçekliğe ilişkin bir ölçü olmasıdır. Janus yüzlü olasılık tamlaması, olasılık ile Janus arasındaki bu benzerlik durumunu anlatmak için kullanılır. Söz konusu tamlamanın 1654-1837 döneminde yaşayan filozoflarca ya da matematikçilerce kabul edilebileceği ileri sürülebilir; çünkü o dönemde olasıllk öznel ve nesnel gerçekliklere ilişkin ölçüleri eş zamanlı olarak dile getirebilen bir sözcük olma özelliğini sergiler. Ancak 1837-1843 döneminde olasılığın ikiye bölünmesinden sonra durum değişir. Olasılık, anılan dönemin bitiminden sonra gerek "Gerçek olasılık öznel olasilıktı"” diyenlerce olsun, gerekse "Gerçek olasılık nesnel olasılıktır" diyenlerce olsun yalnızca tek bir gerçekliğe ilişkin ölçü olarak değerlendirilir. İki gerçekliğe ilişkin değil... Olasılıklardan birini onayıp öbürünü yadsıyan bu tutum 1843 'ten 1945 'e dek sürer. 1945 y1lı ile başlayan yeni dönemde Viyana Çevresi'nin merkezindeki düşünür olan Rudolf Carnap’tan farklı bir ses işitilir. Ona göre iki olasılık vardır ve bilim açısından bunların ikisi de yararlıdır. $\mathrm{Bu}$ nedenle iki olasılıktan birinin utkusunu sağlamak gerekmez; gerekli olan, bu iki olasılık arasındaki işbirliğidir. İşbirliği önerisinin ilk uygulamalarından birini Rudolf Carnap'ın öğrencisi Carl Gustav Hempel bilimsel açıklama ve öngörme etkinliklerini betimlerken yapar. Sonra onu Wesley C. Salmon ve başkaları izler. Bütün bunlardan sonra ise olasılık yeniden Janus yüzlü olur. Ancak şunu söylemek gerekir ki Janus yüzlülüğün eski ve yeni görünümleri aynı değildir. Bu çalışma söz konusu durumu sergilemeyi amaçlamaktadır.

Anahtar Kelimeler: Janus Yüzlü Olasılık, Öznel Olasılık, Nesnel Olasılık, Açıklama, Öngörme. 


\title{
Probability: The Old and New Aspects of Janus-Facedness
}

\author{
Assoc. Prof. Dr. Adil Korkmaz ${ }^{1^{*}}$ \\ Ayşenur Avar ${ }^{2}$
}

First received: 29.12 .2018

Accepted: 29.01.2019

\section{Citation:}

Journal of the International Scientific Research (IBAD)

Volume: 4 Issue: 1

Pages: 81-92 Year: 2019

Session: Winter

This article was checked by iThenticate. Similarity Index 02\%

\footnotetext{
1 Akdeniz University, Turkey, adilkorkmaz@akdeniz.edu.tr,
} ORCID ID 0000-0002-2432-518X

2 Akdeniz University, Turkey, aysenuravar@gmail.com ORCID ID 0000-0002-6657-3552

* Corresponding Author

\begin{abstract}
Probability is likened to Roman god Janus whose one face is looking to the past and the other is looking to the future. The reason of such attitude is that probability, on one hand, is a measure related to objective reality and a measure related to subjective reality, on the other. The phrase of Janus-faced probability is used to express this state of analogy between probability and Janus. It can be claimed that the referred phrase may be accepted by the philosophers and mathematicians living in the period of 1654-1837; because in that period the probability exhibits to be a word simultaneously denoting the measures related to subjective and objective realities. This state, however, changes after probability is divided into two parts during the period of 1837-1843. After the end of the mentioned period, the concept of probability is considered as a measure related to only one reality by both people who think "Real probability is subjective probability" and those who think "Real probability is objective probability" but not a measure related to the double realities. Attitude towards approving one type of probability and denying the other type continues until the year 1945. A different idea rises from Rudolf Carnap who is the central thinker of the Vienna Circle. According to him, there are two probabilities and both of them are useful from the point of science. It is because there is no need for one to win over another. What is necessary is cooperation between these two probabilities. One of the first applications of cooperation is done by Rudolf Carnap's student, Carl Gustav Hempel, while delineating scientific explanation and prediction activities. Wesley C. Salmon and others follow him. After all these, probability once again has become Janus-faced. It should be noted that, however, the old and new aspects of Janus-facedness are not the same. This study aims to exhibit the mentioned situation.
\end{abstract}

Keywords: Janus-Faced Probability, Subjective Probability, Objective Probability, Explanation, Prediction. 


\section{GíRIŞ}

Öznel ve nesnel olmak üzere iki tür olasılık vardır. Bunların ortak yanları ikisinin de fiziksel süreçlere ilişkin rasgelelikten doğmuş olmaları; ortak olmayan yanları ise anlamlarıdır. Öznel olasılık bir ilerisürümün doğruluğuna duyulan inanç düzeyi, nesnel olasılık ise bir olayın kolay gerçekleşme düzeyidir. Soyut nitelikte olan kolay gerçekleşme sık gerçekleşme biçiminde somutlaştı̆̆ için nesnel olasılık uzun dönemdeki göreceli sıklık aracılığı ile ölçülür. Benzer bir durum öbür olasılık için de geçerlidir. Nitekim öznel olasılık inanç düzeyini yansıtsa da bu soyut nicelik aracılı̆̆ıyla değil, onun somut nedenleri ya da sonuçları aracılığı ile ölçülür. İnanç düzeyi ve kolaylık düzeyi (göreceli sıklık düzeyi) gibi iki farklı gerçekliğe ilişkin ölçü olabilme özelliğinden ötürü olasılık Roma tanrısı Janus'a benzetilir. Böyle bir tutum sergilemenin nedeni Janus'un bir yüzüyle geçmişe, öbür yüzüyle geleceğe bakmasıdır. Olasılık ile Janus arasındaki bu benzerliği anlatabilmek için yaygınlıkla kullanılan anlatım Janus yüzlü olasılık tamlamasıdır (Cooper, 1965; Hacking, 1991, s. 12; Daston, 1994; Gillies, 2000, s. 18). Hemen şunu belirtmek gerekir ki söz konusu tamlama tarihin bütün dönemlerinde değil ise de en azından iki döneminde kabul görebilir. İlki 1654 yılından 1837 yılına dek uzanan, ikincisi ise 1945 yılı ile başlayıp süreduran dönemdir. İlk dönemin matematikçileri ve filozofları olasılığın eş-anlı olarak inanç ve sıklık ile ilgili ölçüleri yansıtan bir gösterge olarak değerlendirdikleri için Janus yüzlü olasılık tamlamasını içten gelen bir onama duygusuyla kabul edebilirler. Ancak 1837-1843 döneminde olasıllı̆̆n filozoflarca ve matematikçilerce ikiye bölünmesinden sonraki zamanlarda durum öyle olamaz. Çünkü 1843 'ten sonraki y1llarda "Gerçek olasılık öznel olasılıktır" diyenlerce olsun, "Gerçek olasılık nesnel olasılıktır" diyenlerce olsun, olasılık tek bir gerçekliğe ilişkin ölçü olarak değerlendirilir. Olasılıklardan birini onayıp ötekini yadsıyan John Venn ya da Augustus de Morgan gibi filozoflar ve matematikçiler açısından bakıldığında olasılık asla Janus yüzlü değildir. 1945 yılından sonraki zamanlarda ise olasılıklardan birini onayıp ötekini yadsıyan tek olasılıkçılık tutumu son demlerini yaşamaya başlar. Çünkü anılan yıl ile başlayan yeni dönemde Rudolf Carnap (1945) tek olasıllkçılık dönemini aşmaya çabalarken şöyle söyler:

Bilim açısından öznel ve nesnel olasılıkların ikisi de yararlıdır. Bunlar arasında bir çatışmanın sürdürülmesi sonucunda iki olasıllıktan birinin utkusunu sağlamak gerekli değildir. Gerekli olan, bu iki olasılık arasındaki işbirliğidir.

İșbirliği önerisinin ilk uygulamalarından birini Rudolf Carnap'ın öğrencisi Carl Gustav Hempel bilimsel açıklama ve öngörme etkinliklerini betimlerken yapar. Tümdengelimsel-yasaya dayalı açıklama ve öngörme yordamlarında değil ise de tümevarımsal-olasılığa dayalı açıklama ve öngörme yordamlarında iki olasılık arasında işbirliği başlar ve böylece olasılık kaçınılmaz bir biçimde yeniden Janus yüzlü olarak değerlendirilir. Bu yordamlan eleştirerek onlarda düzeltmeler yapan Wesley C. Salmon gibi filozofların getirdikleri açıklama ve öngörme yordamları da olasılığın Janus yüzlülük özelliğini koruyucu nitelikte olur. Ne var ki, bütün bunlar şu gerçeği görmeyi engellememelidir: Olasılığın bugünkü Janus yüzlülüğü, ilk dönemdeki (1654-1837 dönemindeki) Janus yüzlülüğünden çok farklıdır. Bu çalışma bunun nasıl bir farklılık olduğunu sergilemeye odaklanmaktadır.

\section{Olasılıkların Anlamları}

İki olasıllı̆ın ortak olmayan yanları olarak anlamlarını somut bir biçimde görebilmek için gündelik yaşamda karşılaşılabilecek şu tümceye bakmak yeterlidir: Herhangi bir sigara tiryakisinin kanser olma olasılığ y aklaşılk \%20'dir. Buradaki \%20 sayısı sigara tiryakisinin kanser hastalığına yakalanmasının ne denli kolay gerçekleşebilir olduğunu gösteren bir ölçü olarak değerlendirilebilir ise o zaman söz konusu sayı nesnel olasılık ölçüsü olmuş olur. Aynı sayı sigara tiryakisinin kanser hastalığına yakalanmasına ne denli inanıldığını ya da inanılması gerektiğini gösteren bir ölçü olarak değerlendirildiğinde ise söz konusu sayı öznel olasılık ölçüsü olmuş olur. Öyleyse denebilir ki 0 ile 1 arasındaki bir sayının başka başka biçimlerde anlamlandırılmalarına öznel ve nesnel olasılıklar eşlik etmektedir. Nesnel olasılık olayların ne denli kolay gerçekleştiklerini gösteren bir nicelik olarak betimlenir ise de onların ne denli sık gerçekleştiklerine bakılarak ölçülür. Bunun nedeni, kolay gerçekleşme kavramının soyut, sık gerçekleşme kavramının ise somut olmasıdır. İkinci değerlendirme birincisinin ete kemiğe büründürülmüş biçimi olmaktan başka bir anlam taşımaz. $\mathrm{Bu}$ değerlendirme göz önünde bulundurulduğunda denebilir ki uzun dönemde yinelenen denemelerin hepsinde gerçekleşen bir olayın 
olasılığı 1, hiçbirinde gerçekleşmeyen bir olayın olasıllğı 0 , yarısında gerçekleşip yarısında gerçekleşmeyen bir olayın olasılığı ise $1 / 2$ olur. Bu ölçme yöntemi Richard von Mises'in sıklıkçı olasılık (frequency interpretation of probability) öğretisi için geçerli olduğu gibi, Karl Raimund Popper'ın yönelimci olasılık öğretisi (propensity interpretation of probability) için de geçerlidir (Popper, 1959; Daston, 1994; Galavotti, 2005, s. 81; Zabell, 2011). Öznel olas1lık ise bir ilerisürüme (hypothesis) ne denli inanıldığını ya da inanılması gerektiğini gösteren bir nicelik olarak betimlenir. Bu olasılık söz konusu ilerisürüme hiç inanmama durumunda 0 , tam inanma durumunda 1 , yarı inanma-yarı inanmama durumunda ise 0.5 olur ( $1 / 2$ değil, 0.5 ; çünkü nesnel olas1lık bir oran iken öznel olasıl1k bir düzeydir.). Öznel olasılığın bir türü olan mantıksal olasılığı ölçmede John Maynard Keynes'in kayıtsızlık ilkesi ya da Pierre-Simon Marquis de Laplace'ın eş-olabilirlik ilkesi etkilidir. Bu ilkeye göre $n$ sayıda karşıt ilerisürüm varsa ve bunlardan birine ötekilerden daha çok inanmak için bir neden yoksa o zaman her ilerisürüme atanan olasilık $1 / n$ olur. 20. yüzyılda Frank Plumpton Ramsey ile Bruno de Finetti'nin savundukları ruhbilimsel olasılığın ölçümünde ise yitirilecek değerin kazanılacak değere oranı kullanılır (Gillies, 2000, s. 50-87). Bu oran bahis oranıdır. Burada yitirilecek değer, bir ilerisürüme olasılık atayan oyuncunun masaya koyduğu değerdir. Kazanılacak değer ise masadaki toplam değerdir. Toplam değer oyuncunun ve karşı oyuncunun masaya koydukları değerler toplamıdır.

\section{Olasılıkların Ortak Kaynağı}

Anlamları bakımından farklı olan öznel ve nesnel olasılıkların ortak bir kaynaktan, fiziksel süreçlerdeki rastgelelikten ${ }^{1}$ filizlenmeleri şu soruları gündeme getirmektedir: Rastgelelik nedir? Nerede var olur? Nerede var olmaz? Öznel ve nesnel olasıllkların rastgelelik ile ilişkileri nedir? $\mathrm{Bu}$ soruları yanıtlayabilmek için fiziksel bir sürecin sonucunun bilinip bilinemeyeceğine bakmak gerekir. Fiziksel bir sürecin sonucu ancak ve ancak onu etkileyen doğa yasalarına ve başlangıç koşullarına ilişkin tümceler varsa bilinebilir. Burada doğa yasalarını ve başlangıç koşullarını dile getiren tümceler kristal küre işlevini yerine getirir. ${ }^{2}$ Nasıl masalların kristal küresine bakan bir cadı hangi olayın nerede ve ne zaman gerçekleşeceğini ya da gerçekleştiğini biliyorsa fiziksel süreç ile ilgili bu tümcelere bakan bir kişi de o fiziksel sürecin nasıl sonuçlanacağını ya da sonuçlandığını öyle bilir. Böyle bir kristal küre varsa fiziksel sürecin sonucu bilinebileceğinden orada rastgeleliğin olmadığı söylenebilir. Rastgeleliğin olmadığı bir yerde olasıllk da yoktur. Rastgeleliğin fiziksel sürecin sonucunun bilinemezliğinden doğduğunu görebilmek için en tanıdık örneklerden biri olan paranın havaya firlatılması denemesine bakılabilir. David Ruelle (1995, s. 2) tek bir para havaya firlatıldığında o paranın yazı mı, yoksa tura mı geleceğinin öngörülemez olduğunu, o nedenle böyle bir fiziksel süreçte rastgelelik olduğunu; buna karş1lik birçok para havaya firlatıldığında onların yaklaşık yarısının yazı, yarısının tura geleceğinin öngörülebilir olduğunu, o nedenle de böyle bir fiziksel süreçte rastgelelik olmadığını söyler. Benzer tümceler başka yazarlarda da gözlemlenir. Örnek olarak "Rastgelelik Öngörülemezliktir (Randomness is Unpredictability)" başlıklı bir makale yazmış olan Antony Eagle (2005) gösterilebilir. Eğretileme ile anlatılırsa denebilir ki fiziksel bir sürece ilişkin kristal küre yok ise fiziksel sürecin sonucu bilinemez. $\mathrm{Bu}$ durumda fiziksel sürecin rastgele olduğu söylenir. Böyle bir sürecin sonucu da rastlantı (bir anlamda şans) diye adlandırılır. ${ }^{3}$

Rastgelelik ve rastlantı kavramlarını somutlaştırabilmek için şu örnekten yararlanılabilir: İki arkadaş bir filmi izlemek üzere saat 20.00 'da sinemanın önünde buluşmaya karar verip evlerinden ayrilsalar ve saat 20.00 'da sinemanın önüne gelseler birbirlerine sarılarak "Bu ne rastlantı!" ya da "Bu ne şans!" demezler. Buradaki fiziksel süreç rastgele olmadığı gibi, bu sürecin sonucu da rastlantı değildir. Çünkü her iki kişinin sözlerini tutan varlıklar olmaları ve birbirleriyle buluşmaya söz vermiş olmaları gerçeğini anlatan tümceler burada kristal küre işlevini yerine getirirler ve o kristal küreye bakanlar da bu kişilerin sinema önünde buluşacaklarını bilebilirler. Ancak yukarıdaki iki kişi birbirleriyle haberleşmeksizin evlerinden ayrılsalar ve sinemanın önüne gelip de orada karşılaşsalar o anda birbirlerine sarılarak karşılaşmalarını bir rastlantı ya da bir şans olarak nitelendirebilirler. Çünkü onlardan herhangi birinin evden sinemaya uzanan öyküsü (fiziksel sürecin iki parçasından biri) ötekisi açısından bir tümce ile betimlenemez ve

\footnotetext{
${ }^{1}$ Fiziksel süreçlerdeki rastgelelikten başka bir de matematiksel dizilerdeki rastgelelik vardır (Eagle, 2005).

2 Chaitin (1975) ya da Kolmogorov ve Uspensky (1988) örneklerinde matematiksel dizileri betimleyen ve onlardan daha kisa olan bir algoritma bir kristal küre olarak anlamlandırılabilir.

3 Rastlantı ve şans kavramlarının birbirlerinin yerine kullanımları için Çalışkan (2018, s. 13-25) önerilebilir.
} 
kristal küre işlevini gören tümce yokluğu nedeniyle de sinemanın önünde gerçekleşen karşılaşma bilinemez. Burada rastgeleliğin bilen varlık (özne) ile mi, yoksa bilinen varlık (nesne) ile mi ilgili olduğu sorusu yöneltilebilir. Aynı soru rastlantı için de yinelenebilir. Birçok filozof rastlantıyı bilinen varlıktan çok bilen varlıkla ilgili görür. Rastgeleliği, doğaya ilişkin bir özellik olarak değil de doğa hakkında ne bildiğimiz ve ne söyleyebileceğimiz ile ilgili bir özellik olarak gören Kyburg (1972) bunlardan biridir. Benzer düşünceleri savunanlar arasında David Hume gibi ünlü filozoflar ya da Pierre-Simon Marquis de Laplace gibi ünlü matematikçiler de vardır. David Hume (2017, s. 55) ilk kez 1751 yılında yayınlanan An Enquiry Concerning Human Understanding (İnsanın Anlama Yetisi Üzerine Bir Soruşturma) adlı yapıtında bu konuyla ilgili olarak şöyle yazar:

Dünyada rastlantı diye bir şey yoktur, ama bir olayın gerçek nedenini bilmememiz anlama yetimizi böyle etkiler ve bu tür bir inanç ya da kanı doğurur.

Rastlantıyı doğadan uzaklaştırıp bilme çabası içindeki kişi ile ilişkilendiren bu yaklaşımın uzantısını Pierre-Simon Marquis de Laplace'da (2012, s. 4) da görmek olanaklıdır. Fransa'nın Newton'u diye nitelendirilen bu matematikçiye göre doğanın bütün yasalarını ve herhangi bir andaki bütün koşullarını bilen bir zekâ evrenin geçmişini, şimdisini ve geleceğini bilir. $\mathrm{O}$, bu sözleriyle evrenin bütün yasalarını ve herhangi bir andaki bütün koşullarını bilen bir zekâ açısından rastgeleliğin olmadığını söylemekten başka bir iş yapmaz. Rastgelelik yoksa öngörülemezlik ve dolayısıyla rastlantı da yoktur. Rastlantı nedir bilmeyen böyle bir zekâ açısından elbette 0 ve 1 dışındaki olasılıklar da yoktur. 0 ile 1 dışındaki olasılıklar yalnızca böyle bir zekâdan yoksun varlıklar için söz konusu olabilir. Dolayısıyla rastgelelik insanın bilmeyle ilgili eksiklikleri üstünde yükselen bir kavram olur. Pierre-Simon Marquis de Laplace'ın anlatımlarından şu da çıkarımlanabilir: Rastgelelik, raslantı ve olasılık kavramları evrenin tümcelere sığmayan -anlatılmaz- karışıklığı üstünde yükselen kavramlardır. Benzer bir görüşü Henri Poincaré (1912) da dile getirir:

(i) Çok sayıdaki etkenler arasında göz önünde bulundurulmayanlar varsa bunlar nedeniyle fiziksel sürecin sonucu öngörülemez olur. ${ }^{4}$

(ii) Bir etken göz önünde bulundurulsa bile onun ölçümünde yapılacak küçük bir hata beklenmedik büyük sonuçlar yaratabileceğinden fiziksel sürecin sonucu gene öngörülemez olur. ${ }^{5}$

İkinci şıkta anlatılan rastgelelik kaynağı birinci şıkta anlatılan rastgelelik kaynağına eklenebilir; çünkü göz önünde bulundurulan bir etkenin ölçümünde yapılan küçücük bir hata da bir etkendir, üstelik doğası gereği göz önünde bulundurulmayan bir etken. Yukarıdaki anlatımlar yalnızca rastgeleliğin kara kutusunu açma bakımından değil, rastlantıda doğanın bir payı olduğunu dile getirmeleri bakımından da dikkat çekicidir. Öyleyse bir süreç tümcelerle dile getirilemeyecek ölçüde karışık olduğunda onun sonucu da öngörülemeyen bir olay -kısaca rastlantı- olup çıkar. Öyleyse rastgelelik bir yandan doğanın karışıklığından, bir başka yandan da onu bilme çabası içindeki kişinin anılan karışıklığı betimleyen kristal küre tümcelerini bulamamasından doğar. Olasılık da buradan filizlenir. Nesnel olasıllk raslantının olmaktaki kolaylığından ya da olmaktaki sıklığından, öznel olasılık ise raslantıyla ilgili bir ilerisürüme yönelik inanç düzeyinden...

\section{3. İki Olasılık Arasındaki İlişki}

Anlamları ayrı, kaynakları bir olan öznel ve nesnel olasılıklar arasındaki ilişki Sindirella'nın ayağı ile kundurası arasındaki ilişkiye benzetilebilir. Kundura ayaktan küçük, ona eşit ya da ondan büyük olabilir. Nasıl ayak ile kundura birbirlerine eşit olduklarında bile doğaları bakımından bambaşka iseler, tıpkı onlar gibi, öznel olasılık ile nesnel olasılık da birbirlerine eşit olduklarında bile doğaları bakımından bambaşkadırlar. İki olasılığın birbirlerine eşit olmaları ilişkisi burada iki olasılık arasında işbirliği diye adlandırılmaktadır. İşbirliği, nesnel olasılığa bakarak öznel olasılığı, öznel olasılığa bakarak da nesnel olasıllğı belirleme demektir.

\footnotetext{
${ }^{4}$ Herakleitos’un (2003, s. 21; 2005, s. 49) «Bir varlıktan bütün varlıklar, bütün varlıklardan bir varlık» biçiminde dile getirilen eksiltili anlatımı «Bir varlıktan bütün varlıklar, bütün varlıklardan bir varlık etkilenir» biçiminde anlaşılırsa o zaman doğadaki her olup biten sonuç bir rastlantı olarak bile değerlendirilebilir.

5 15. yüzyılda Sufilerin «Yeryüzünde bir çiçeği sapından tutup salla, gökyüzünde yllızlar titrer» sözü bu durumun şïrsel bir anlatımı olarak değerlendirilebilir (Fiş, 1995, s. 142).
} 
Olasılık kuramının başlangıç yıllarında olasılı̆̆ın Janus yüzlü olduğuna bakılarak iki olasılık arasında sarsılmaz bir işbirliği olduğu savı ileri sürülebilir. Gerçekten de iki olasıllk 1654-1837 döneminde oksijen ile hidrojenin varlıklarını suda tekleştirmiş olmalarına benzer bir biçimde tekleşmişlerdir. $\mathrm{O}$ dönemde var olan, öznel ve nesnel olasılıklar değil, yalnızca onların birleşik biçimi olan olasılıktır. Bu durumu gösteren kanttları Gottfried Wilhelm Leibniz, Jacob Bernoulli ya da Pierre-Simon Marquis de Laplace örneklerinde görmek olanaklıdır. Örneğin şu söz Gottfried Wilhelm Leibniz'e ilişkindir (Hacking, 1991, s.128):

Quod facile est in re, id probabile est in mente. (Bir olayın gerçekleşeceğine duyduğumuz inancın yüksekliği onun evrendeki olup bitme kolaylı̆̆ına bağlıdır.)

Bu sözün gönderme yaptığı iki gerçeklik vardır. İlki, bir olayın evrende kolay olması gerçekliğidir. Bu, nesnel olasilıktır. Ötekisi ise bir olayın gerçekleşeceğine duyulan inanç düzeyidir ki bu da öznel olasılıktır. İki olasılık eşit olduğundan onlar arasında işbirliğinin var olduğu söylenebilir. İkinci kanıt Jacob Bernoulli'nin büyük sayılar yasasından elde edilebilir. Jacob Bernoulli kendi anlatımına göre uzun süre çalışarak kanitlayabildiği bu yasasında a priori (önsel) olarak belirlenen öznel olasılık ile $a$ posteriori (sonsal) olarak belirlenen nesnel olasılığı buluşturur. Üçüncü kanıt Pierre-Simon Marquis de Laplace örneğinde bulunabilir. Pierre-Simon Marquis de Laplace da olasılığı tanımlarken anahtar kavram olarak eş ölçüde kolay olabilme anlamındaki eş-olabilirlik (equi-possibility) kavramını kullanır. Bu kavram olmaktaki kolaylık ile ilgili olduğundan nesnel olasılık ile de ilgilidir. Söz konusu kavramı açık seçik biçimde anlatmak isteyen Pierre-Simon Marquis de Laplace bu kez eş ölçüde karar verilemezlik kavramını kullanır. Bu ise öznel olasılığın temelindeki kavramdır. Eş-olabilirlik ile eş-karar verilemezlik kavramlarını eşdeğer saymak ise iki olasılık arasında işbirliğinden başka bir anlama gelmez.

İki olasılık 1837 yılından önceki zamanda işbirliği içindedir ancak bu sav 1837-1843 döneminde olasılığın bölünmesinden sonra söylenemez. Gerçi bu dönemden sonra da iki olasılık arasında işbirliği olur; ancak filozoflar ve matematikçiler iki olasılıktan birini gerçek olasılık diye adlandırıp ötekini gerçek olasılık diye adlandırmadıklarından yaptıkları iş onlara iki olasılık arasında işbirliği olarak gelmez. John Venn buna bir örnektir. Anılan ünlü matematikçi bir yazısında şöyle yazar: "Olasılığın $a$ priori olarak belirlenmesi onu öznel yapmaz, çünkü o nesneldir" (Galavotti, 2005, s. 74). Oysa a priori olarak belirlenen olasılık öznel olasılıktır; nesnel değildir, çünkü uzun dönemdeki göreceli sıklık ile nicelleştirilen nesnel olasılık a posteriori olarak belirlenir. John Venn'in nesnel olasılı̆̆ a priori olarak belirlemesi önce öznel olasılığı belirlemesi, sonra da burada belirlediği değeri nesnel olasılığa atayarak onu da belirlemesi demektir. Bu da iki olasılık arasında işbirliğinden başka bir anlama gelmez. Ancak John Venn öznel olasılığı gerçek olasılık diye görmediğinden yaptığı işi iki olasılık arasında işbirliği olarak görmez. Bu da demektir ki olasılıklardan birini yadsıyan John Venn açısından olasılık Janus yüzlü değildir. Benzer bir söz Augustus de Morgan için de yinelenebilir (Galavotti, 2005, s. 136); çünkü "Nesnel olasılı̆̆ çöpe atıyorum" diyen bir matematikçi açısından bakıldığında da olasılık Janus yüzlü olamaz. Her ne denli iki olasılıktan birini göklere çıkarıp ötekini yerlere batıranlar olasılığın ne olduğu konusunda uzlaşamazlar ise de onun tekliği konusunda en küçük bir kuşkuya bile yer kalmaksızın uzlaşırlar. Onlar "Gerçek olasılık öznel olasılıktır" ile "Gerçek olasılık nesnel olasılıktır" savlarından birini onarlar, ancak ikisini birden onamazlar. Bu da demektir ki onlar olasılığı Janus yüzlü olarak görmezler.

Tek olasılıkçılar iki kampa ayrıldıktan sonra zaman zaman bunlardan biri, zaman zaman da öbürü baskınlaşır; ancak onlardan herhangi biri öbürüne göre utku kazanamaz. İki kamp arasındaki çatışmanın sona ermesi konusundaki görüşler ilk kez 1945 yılında çok güçlü bir biçimde fillizlenir. Anılan yılda Rudolf Carnap, biri öznel, öbürü nesnel olmak üzere iki olasıllğın var olduğunu, bunlardan birinin olasılık 1 (öznel olasılık), öbürünün olasılık 2 (nesnel olasılık) diye adlandırılabileceğini ve bu olasılıkların bilim açısından yararlı olduklarını söyler (Carnap, 1945). Ona göre bu iki olasılık arasında bir çatışmanın sürdürülmesi sonucunda iki olasılıktan birinin utkusunu sağlamak gerekmez; gerekli olan, bu iki olasılık arasındaki bir işbirliğidir. David Lewis bu önerinin artık tartışma dışı olması gerektiğini şu sözlerle dile getirir (Lewis, 1980):

Biz öznel olasılıkçılar olasılığı ussal inanç düzeyi olarak düşünüyoruz. Gel gör ki böyle düşünsek de öteki olasılık anlamlandırmalarına karşı bir savaş başlatmak da istemiyoruz. Yalnızca şunu söylüyoruz. Bizim olasılığımızın bitirildiği bir yerde bir iş başlatılamaz. 
Olasılıklar arasında bir savaş başlatmamayı dile getiren bu sözler Rudolf Carnap'ın önerisine uygundur, çok yerindedir de. Çünkü, ileride gösterileceği gibi, iki olasılıktan birinin yok edildiği bir yerde bilimin açıklama ve öngörme diye adlandırılan en yüksek iyileri (summum bonum) tümevarımsal biçimde yapılamaz; salt tümdengelimsel biçimde yapılabilir.

\section{1. İşbirliği Koşulu}

İki olasılık eşit olacak mı, olmayacak mı? Eşit olacak ise ne zaman? Bu sorunun yanıtı şöyledir: İki olasılık kabul edilemez bilgi varsa eşitlenemez, yoksa eşitlenebilir (Lewis, 1980; Thau, 1994; Strevens, 1995; Strevens, 1999; Arntzenius ve Hall, 2003). Peki, hangi bilgiler kabul edilebilir, hangi bilgiler kabul edilemezdir? Filozoflar en azından kabul edilemez bilginin ne olduğu konusunda uzlaşmışlardır. Kabul edilemez bilgi iki olasılık arasında bir işbirliğini engelleyen bilgidir. Örnek olarak ilerisürüm konusunda kristal küre örneğinde de görüldüğü üzere doğrudan doğruya çıkarım sağlayan bilgi kabul edilemez bilgidir. Kabul edilebilir bilgi ise öznel olasılığı değiştirmediği için ilerisürüm ile ilgili olmayan (irrelevance) bilgi demektir. Örneğin $\mathrm{h}=$ "Bugün Erciyes dağında hava sicaklığ $1-25{ }^{\circ} \mathrm{C}$ olacak", $\mathrm{K}=$ "Denizler geç 1sınır, geç soğur" olsun. $\mathrm{P}(\mathrm{h} / \mathrm{K})=\mathrm{P}(\mathrm{h})$ ise o zaman şu söylenebilir ki $\mathrm{K}$ bilgisi $\mathrm{h}$ ilerisürümüne iliştirilen olasıllı̆ı etkilememektedir. Olasılığı etkilemeyen bilgi kabul edilebilir bilgi, etkileyen bilgi ise kabul edilemez bilgi diye adlandırılır (Strevens, 1995; Strevens, 1999). Bütün bilgiler kabul edilebilir bilgi ise o zaman nesnel olasılığın kaç olduğunu öğrenen biri öznel olasılığını ona eşit olacak biçimde belirleyebilir. Ancak kabul edilemez bilgi varsa öznel olasılık nesnel olasılığa bakılarak değil, kabul edilemez bilgiye bakılarak belirlenebilir. Bu da demektir ki böyle durumlarda olasılıklar arasında işbirliği yapılamaz.

\subsection{1. İki Olasılık Arasında İşbirliği Yapılamaması Durumları}

İki olasılık arasında işbirliği olmayabileceğine ilişkin birçok örnek verilebilir: (i) Bir makalede sigaranın kanser yapma olasılığı \%20 olarak saptanmış olsun. Bu makaleyi okuyan bir kişi \%20 sayısını yanlışlıkla $\% 2$ olarak okursa nesnel olasılık \%20 ve öznel olasıllı \%2 olduğundan iki olasılık arasında işbirliği amaçlansa da gerçekleşmez. (ii) Bir kavanozdaki kurdelelerin hepsinin kızıl ya da hepsinin kara olduğu bildirildikten sonra bu kavanozdan çekilecek bir kurdelenin kızıl olma olasılığı kaçtır diye sorulursa buna iki farklı yanıt verilebilir. " "Olasılık 0.5'dir" diyen kiși öznel olasılığı dile getirmiș olur. Çünkü kavanoz bütün kurdeleleri kızıl olan bir kavanoz ise ondan çekilecek kurdele kesinlikle kızıldır; yok, o kavanoz bütün kurdeleleri kara olan bir kavanoz ise o kavanozdan çekilecek kurdele de kesinlikle karadır. $\mathrm{Bu}$ ilerisürümlerden birine ötekinden daha çok inanmak için bir neden olmadığına göre John Maynard Keynes'in kayıtsızlık ilkesi gereğince her iki ilerisürüme de eşit ölçüde inanmak gerekeceğinden o ilerisürümlerin her birine 0.5 olasılığını iliştirmek gerekir. Aynı soruya "Olasılık 0 ya da 1'dir; ancak hangisidir bilmiyorum" diyen kişi ise nesnel olasıllığ dile getirir. Çünkü kavanoz bütün kurdeleleri kızıl olan bir kavanoz ise kızıl kurdele çekmenin göreceli sıklığı 1 olur; yok, söz konusu kavanoz bütün kurdeleleri kara olan bir kavanoz ise kızıl kurdele çekmenin göreceli sıklığı 0 olur. Göreceli sıklık ile ilgili bu sav uzun olsun kısa olsun bütün dönemlerde geçerlidir. Öznel olasılığın 0.5 , nesnel olasılığın 0 ya da 1 olması ise iki olasılık arasında eşitlik ilişkisinin olmaması demektir. (iii) Kristal kürenin var olması durumunda işbirliği olanaksızdır. Burada masallardan alıntılanan bir kavram olarak kristal küre neyin, ne zaman, nerede gerçekleşeceğini gösteren bir araç olarak betimlenebilir. Kristal küreye örnek olarak Pierre-Simon Marquis de Laplace'ın cini (Laplace's demon) gösterilebilir. Bu saymaca varlık hangi olayın ne zaman ve nerede gerçekleştiğini de, gerçekleşeceğini de bilen bir varlık olarak betimlenir. Böyle bir varlıktan bilgi elde eden herhangi bir kişinin kristal küreye sahip olduğu söylenebilir. Kristal küreye sahip olan herhangi bir kişi açısından ise yalnızca ve yalnızca 0 ya da 1 değerlerinde öznel olasılıklar vardır. Oysa nesnel olasılıklar çoğu kez 0 ile 1 arasındadırlar. Bu da kristal küreye sahip olan kişiler açısından öznel ve nesnel olasılıkların eşit olamayabilecekleri anlamına gelir. Şu örnekte bu durumu görmek olanaklıdır: Bir hava durumu sunucusu "Bugün yağmur yağma olasılığı \% 75'tir" dediğinde nesnel olasıllğı dile getirmiş olur. Bu hava durumu sunucusunu dinleyenler geleceği öngörmeyi sağlayan bir tümceden yoksunsalar öznel olasılıklarını 0.75 sayısına eşit olacak biçimde ayarlayabilirler. Ancak geleceği öngörme olanağı sağlayan bir tümcesi olanlar hava durumu sunucusunun söylediklerine değil, bu tümcelerine bakarlar. Romatizma ağrıları yağmur yağmasının

\footnotetext{
${ }^{6}$ Bu örnek Maher (2010)'deki bir örneğin değiştirilmiş bir biçimidir.
} 
belirtileri ise o zaman "Romatizma ağrıları nüksetti" ya da "Romatizma ağrıları nüksetmedi" gibi tümceler kristal küre olarak işlev görürler. Böyle tümceleri olan bir kişi öznel olasılığını 0.75 olarak değil, ilk tümcede 1 , ikincisinde 0 olarak belirler.

\subsection{2. İki Olasılık Arasında İşbirliği Yapılabilmesi Durumları}

Leonard Jimmie Savage'ye (1951) göre geleneksel olarak kabul edilir ki istatistiğin merkezsel sorunu istatistiksel çıkarımlar yapmaktır. İstatistiksel çıkarımlar yapmak ise eksik bilgiye dayalı olarak ussal, güvenilir ve bilgiye dayalı tümceler elde etmektir. İki olasılık arasında işbirliği örnekleri olarak kendilerini ortaya koyan açıklama ve öngörme etkinlikleri ise böyle tümceler elde etme biçimleri olarak görünürler.

\subsubsection{Açıklama ve Öngörme}

Carl Gustave Hempel ile Paul Oppenheim birlikte yazdıkları bir makalede açıklamanın "Ne? (What?)" sorusundan çok "Neden? (Why?)" sorusunu yanıtlama olduğunu söylerler (Hempel-Oppenheim, 1948). Ernst Nagel de bu görüşü paylaşır. Ernst Nagel (2013, s. 30) ilk kez 1979 yılında yayınlanan "Bilimin Yapısı (The Structure of Science)" adlı yapıtında şunu söyler: Açıklama demek olup bitenler neden olup bitiyor sorusunu yanıtlamak demektir. Carl Gustave Hempel'in ve Ernst Nagel'in açıklama yordamları benzerdir. Ortada açıklanacak olaya ilişkin bir tümce vardır. Bu tümce tümdengelimle öncüllerden çıkarımlanacaktır. Carl Gustav Hempel buna explanandum der (Ernst Nagel bunu explicatum diye adlandırır). Bir de onu açıklamakta kullanılacak tümceler vardır. Carl Gustave Hempel'e göre bunlardan en az biri yasa niteliğinde tümce olmalıdır. Söz konusu tümcelere öncüller denir. Carl Gustav Hempel öncülleri explians diye adlandırır. Açıklama demek, explanandum tümcesini öncüllerden türetmek demektir.

Açıklanacak pek çok olgu sıralanabilir: Yazın elektrik telleri neden uzar? Sabahları toprağı, çimenleri, yaprakları neden kırağı kaplar? Yağmur çiselediğinde sırtını güneşe dönen gözlemci neden gökkuşağı görür? $\mathrm{Bu}$ ve bunun gibi sorulardan herhangi birini yanıtlayarak yapılacak bir açıklamanın başarılması çıkarım için temel oluşturacak doğa yasalarını ve başlangıç koşullarını dile getiren tümcelerin varlığına bağlıdır. Carl Gustav Hempel'e göre açıklama ile öngörme yordamları arasındaki tek fark açıklanacak olgunun geçmişte, öngörülecek olgunun ise gelecekte olması olduğundan benzer bir söz öngörme etkinliği için de yinelenebilir. Onun en çok eleştirilen savı bu konuyla ilgilidir ve o da "Geçmişteki bir olguyu açıklamada ve gelecekteki bir olguyu öngörmede yararlanılacak yordam aynıdır" biçiminde dile getirilebilir. Bu konuda geniş bir inceleme için Salmon (1989) önerilebilir. Carl Gustav Hempel gerek açıklama, gerekse öngörme için iki yordam önerir (Hempel-Oppenheim, 1948; Hempel, 1965, s. 131; Tağman, 2014):

(i) D-N yordamı: Bu yordam adını deductive-nomological sözcüklerinin baş harflerinden alır. Söz konusu sözcükler de tümdengelimsel-yasaya dayalı anlamlarına gelir.

ii) I-S yordamı: Bu yordam adını inductive-statistical sözcüklerinin baş harflerinden alır. Söz konusu sözcükler de tümevarımsal-istatistiğe dayalı anlamlarına gelir. Kimi yazarlar istatistiğe dayalı tamlaması yerine olasılığa dayalı tamlamasını kullanmaktadırlar. Burada da bu tutum yeğlenmektedir.

İlk yordam en yalın biçimde şöyle dile getirilebilir:

(1) Kesin Yasa $^{7}$

(x) $\mathrm{Px} \rightarrow \mathrm{Qx}$

(2) Başlangıç Koşulu

$\mathrm{Pa}$

(3) Açılanacak ya da Öngörülecek Tümce

Qa

\footnotetext{
${ }^{7}$ Mittelstaedt-Weingartner (2005, s. 18) içindeki strict or dynamical law karşllğ̆ olarak önerilmektedir.
} 
Burada tümellikle ilgili olan $\mathrm{x}$ simgesi herhangi bir varlığı, tekillikle ilgili olan a simgesi de şimdi şurada olan varlığı gösterir. (x) simgesi her $\mathrm{x}$ demektir. Onun önünde yer alan $\mathrm{P}$ ve $\mathrm{Q}$ harfleri yüklemleri; $\mathrm{Px}$ ve Qx ise " $x, P$ 'dir" ve "x, Q'dur" tümcelerini gösterir. " $\rightarrow$ ” imi bir yönlü gerektirme anlamına gelen mantıksal "ise"dir. Buna göre "Px $\rightarrow Q x$ " simgesi "Bir varlık $P$ ise o varlık Q'dur" ya da "Bütün P'ler Q'dur" biçiminde okunabilecek bir yasadır. Özel bir durum olarak P="Isınan tel" ve Q="Uzayan tel" olursa kesin yasa "Bütün 1sıtılan teller uzar" ya da "Herhangi bir tel isınır ise o tel uzar" biçimine bürünür. Bu durumda yukarıdaki açıklama kalıbı şöyle dile getirilebilir:

\section{(1) Kesin Yasa}

Bir tel 1sinir ise o tel uzar.

(2) Başlangıç Koşulu

Şimdi şurada olan tel 1sındi.

\section{(3) Açıklanacak Tümce}

O nedenle şimdi şurada olan tel uzadi.

Yukarıdaki anlatımlar "Şimdi şurada olan tel neden uzadı?" sorusunu yanıtlamakta oldukları için Carl Gustav Hempel'in gözünde bir açıklama kimliğini kazanmaktadır. Bu yordamı öngörme yordamına dönüştürmek için zaman kiplerini değiştirmek yeterlidir.

Yukarıda dile getirilen açıklamanın ya da öngörmenin ne öncüllerinde, ne de vargısında olasılık vardır. Tümdengelimsel açıklamalarda ya da öngörmelerde olasılık yoktur. Olasılık tümevarımsal açıklamada ve öngörmede vardır. Carl Gustav Hempel'in anlatımıyla I-S olarak gösterilen ve tümevarımsal-olasılığa dayalı açıklama ya da öngörme yordamının en yalın biçimi şöyledir:

(1) Olasiliksal Yasa ${ }^{8}$

(x) $\operatorname{Prob}(\mathrm{Px} \rightarrow \mathrm{Qx})=\mathrm{r}$

(2) Başlangıç Koşulu

$\mathrm{Pa}$

(3) Açıklanacak ya da Öngörülecek Tümce

$$
\operatorname{Prob}(\mathrm{Q} a)=\mathrm{r}
$$

D-N yordamında olduğu gibi I-S yordamında da x, "herhangi bir varlık"; a "şimdi şurada olan varlık", P ve Q yüklemler; Px ve Qx ise tümceler, $\rightarrow$ imi bir yönlü gerektirme imi (mantıksal ise imi) olmaktadır. Olasılıksal yasadaki ve açılanacak ya da öngörülecek tümcedeki $r$ ise olasılıktır. İlki nesnel, öteki özneldir. Prob işlevi olasılık işlevidir. Tümdengelimsel açıklamada öncüller ile sonuç tümcesi arasında tek çizgi varken tümevarımsal açıklamada çizgi sayısı ikiye çıkmaktadır. İki çizgi çıkarımın olasılıksal niteliğini anlatır.

Yukarıdaki yordamı anlayabilmek için şu özel durum incelenebilir: $\mathrm{P}=$ "'Zil zurna sarhoş araba süren herhangi bir kişi” ve Q="Trafik kazası yapan herhangi bir kişi” olsun. Söz konusu edilen yordama göre açıklama ya da öngörme kalıbı şöyle anlatılabilir:

\footnotetext{
${ }^{8}$ Mittelstaedt-Weingartner (2005, s. 18) içindeki statistical law karşlluğ olarak önerilmektedir.
} 
(1) Olasilıksal Yasa (Olasilık Düzeyi=r)

Herhangi bir kişi zil zurna sarhoş araba sürer ise o kişi çok yüksek bir olasılıkla trafik kazası yapar.

(2) Başlangıç Koşulu

Şu kişi zil zurna sarhoş araba s.

\section{(3) Açıklanacak Tümce (Olasılık Düzeyi=r)}

O kişi çok yüksek bir olasılıkla zil zurna sarhoş araba sürdüğü için trafik kazası yaptı.

Bu açıklamada "Şu kişi neden trafik kazası yaptı?" sorusu yanıtlanmaktadır. Bu yanı "Neden?" sorusunun yanıtı olması nedeniyle bir açıklamadır. Her açıklamada olduğu gibi bu açıklamada da olmuş bitmiş bir olay vardır. Buradaki örnekte bir kişinin yapmış olduğu bir trafik kazası olmuş bitmiştir. Salt bu olay gözlemlenmemiştir, ondan başka trafik kazası yapan kişinin zil zurna sarhoş araba sürdüğü de saptanmıştır. Trafik kazası başka nedenlerle de gerçekleşmiş olabilir, ancak yüksek bir olasılıkla inanılmaktadır ki trafik kazası yapan kişi zil zurna sarhoş araba sürdüğü için (başlangıç koşulu) trafik kazası yapmıştır. Yukarıdaki açıklama kalıbını öngörme kalıbına dönüştürmek için zaman kiplerini değiștirmek yeterlidir.

Carl Gustav Hempel I-S açıklama yordamındaki $r$ olasılığının çok yüksek olması gerektiğini dile getirir. Bunun nedeni açıklamanın doğruluğuna yönelik inancı yükseltmektir. Ancak şu da bir gerçektir ki olasılığın çok yüksek olması açıklamanın doğruluğunu güvence altına alamaz. Olasılık çok yüksek olsa bile yukarıdaki açıklama yanlış olabilir. Örnek olarak henüz saptanamamış bir neden trafik kazasına yol açmış olabilir. Zil zurna sarhoş araba süren kişi yolda giderken kalp krizi geçirmiş ise trafik kazası o nedenle gerçekleşmiş olabilir. O zaman yukarıdaki açıklama doğru olmaz. Öyleyse I-S açıklama yordamındaki $\mathrm{r}$ olasılığı açıklamaya kesinlik değil, yalnızca çok yüksek olasılıklı olma (ussal temele dayalı olarak inanılır olma) özelliğini kazandırır. Carl Gustav Hempel düşük olasılıklı yasaların açıklamalarda kullanımını reddeder (Kitcher-Salmon, 1989, s. 61). Örnek olarak sigara içen insanların kanser olma olasılığı \%20 ise bu yasa açıklamada kullanılamaz; çünkü olasıllk yüksek değildir. İnsanlardaki kanser olma olasılığının \%2 iken sigara içen insanlardaki kanser olma olasılığının kat kat artarak \%20'ye ulaşması bile bu durumu değiştirmez. Carl Gustav Hempel'in böyle bir özellik sergileyen açıklama yordamı pek çok kez eleştirilir. Eleştirenlerden biri Isaac Levi'dir. Ona göre Carl Gustav Hempel'in tümevarımsal-olasıllğa dayalı açıklama ve öngörme yordamı ya bütünüyle bir yana bırakılmalı, ya da çok geniş kapsamlı olarak düzeltilmelidir (Levi, 1969). Wesley C. Salmon da I-S yordamını eleştirir. $\mathrm{O}$, sigara içme ile kanser olma arasındaki olasılık bakımından yüksek olmayan ilgililik (relevance) durumunun I-S yordamında kullanılamazlığını arızalı bir durum olarak görür ve kendi S-R yordamını (statistical-relevance model) önerir (Salmon, 1989, s. 62). Bu yeni yordamda olasılıksal yasa ilgililik temeli üstünde yükselen ancak çok yüksek değerler almak durumunda olmayan bir olasılıksal yasadır. Öyleyse Wesley C. Salmon açıklama ya da öngörme yordamlarındaki olasılıksal yasa konusunda bir yenilik getirmiş olmaktadır. Bu durumda şu soru yöneltilebilir: S-R yordamında olasılıksal yasa değişirken öznel ve nesnel olasılıklar arasındaki işbirliği değişmekte midir? Yanıt olumsuzdur. İki olasılık arasındaki ilişkide herhangi bir değişiklik olmaz. Öznel olasılık ile nesnel olasılıklar bu yordamlarda da işbirliklerini gene sürdürürler. Wesley C. Salmon I-S yordamıyla ilgili bir eleştiri daha yapar. Bu eleştiri olasılıksal yasadaki olasılığın anlamlandırılması konusundadır. Wesley C. Salmon bu olasılığın yatkınlık (dispositional probability) ya da yönelim (propensity) olduğundan kuşkuludur. O bu kuşkularını Paul Humphreys ile yaptığı konuşmalardan elde eder. Paul Humphreys ise 1985 yılında yazdığı bir makalede yönelimci olasılığın neden olasılık olamayacağını anlatmaya çabalayan kişidir (Humphreys, 1985).

Buradaki çalışma açısından şu söylenebilir: Paul Humphreys'in tümevarımsal yasadaki olasılığın ne olduğu konusunda Wesley C. Salmon'da yarattığı kuşkuların haklı olup olmaması buradaki çalışma açısından herhangi bir fark yaratmamaktadır. Çünkü bu kuşkular nesnel ve öznel olasılıklar arasındaki işbirliği gerçeğini değiştirmemektedir. Tümevarımsal yasadaki olasılık nesnel olasılıktır ve bu da uzun dönemdeki göreceli sıklık ile ölçülmektedir. Açıklanacak tümcedeki olasılık ise hâlâ öznel kalmayı sürdüren bir olasılıktır; çünkü bu olasılık açıklanacak tümceye duyulan inanç düzeyini göstermektedir. 


\section{SONUÇ}

Janus yüzlü olasılık, öznel ve nesnel olmak üzere iki olasılı̆̆ın var olduğunu dile getiren bir anlatımdır. $\mathrm{Bu}$ anlatım tarihin bütün dönemlerinde değil ise de en azından iki döneminde içten gelen bir onama duygusuyla benimsenebilecek niteliktedir. İlki 1654 ile 1837 arasındaki, öteki ise 1945'te başlayıp süreduran dönemdir. İlk dönemde filozoflar ve matematikçiler olasılığa baktıklarında tek bedende yuvalanan iki ruh görürler: Bir sonucun olup bitmesindeki kolaylık düzeyi ile o sonucun olup biteceğine duyulan inanç düzeyi. Böyle gördüklerinden ötürü de Janus yüzlü olasılık tamlamasını içten gelen bir onama duygusuyla benimseyebilirler. Oysa 1837-1843 yıllarında yaşayan filozoflar ve matematikçiler öncülerine göre bambaşka bir yol tutarlar: Bir bedendeki iki ruhu birbirlerinden kesin bir biçimde ayırırlar. Onlardan birini öznel olasılık, öbürünü nesnel olasılık diye adlandırılması yoluna girerler. Sonra da "Hangi olasılık gerçek olasılıktır?" diye tartışırlar. Tartı̧malarla geçen uzun bir dönem içinde olasılıklardan birini onayıp ötekini yadsırlar ancak ikisini birden onamazlar. Olasılıklardan salt birini gerçek olasılık diye değerlendirirler, ötekini ise öyle değerlendirmezler. O nedenledir ki bu dönem matematikçilerinin ve filozoflarının Janus yüzlü olasılık tamlamasını içten gelen bir onama duygusuyla benimseyebileceklerini ileri sürmek tutarl11ıkla bağdaşmaz. Tek olasıllkçılığın bir ürünü olan bu tutum 1945 yılına dek dipdiri kalır. Ne var ki, 1945 yılından sonra Rudolf Carnap'ın çığır açan çalışmaları nedeniyle iki olasılıktan birini yadsıyı öbürünü onama tutumu artık sürdürülemez olur. Böylece tek olasılıkçılığ geride bırakan yepyeni bir dönem başlamış olur. Elbette bu yeni dönemde filozofların ve matematikçilerin hepsinin değil ise de bir bölümünün Janus yüzlü olasılık tamlamasını içten gelen bir onama duygusuyla benimsemeye yatkınlaştıkları kabul edilebilir. Ancak bunu yaparken şu gerçeği de gözden rrak tutmamak gerekir: Bu yeni dönemdeki Janus yüzlülük eski Janus yüzlülüğün geri gelmesi niteliğinde değildir. Çünkü iki döneme ilişkin Janus yüzlülükler bambaşkadırlar. İlk dönemdeki Janus yüzlülük iki olasılı̆̆ın kaynaşması biçimindedir. Olasılıklardan biri öbüründe yitip yok olmuş gibidir. O nedenle olasılığa bakan bir kişi onda öznel ve nesnel gerçekliklere ilişkin ölçüler olma özellikleri görse bile onları ayrı ayrı ölçüler olarak değil, tek bir ölçü olarak değerlendirir. Oysa 1945 'ten sonra gelen yeni dönemdeki Janus yüzlülük tek bedende iki ayrı ruh değil, iki ayrı bedende iki ayrı ruh olma biçimindedir. Öznel ve nesnel olasılıklar çatışmaksızın ve biri ötekinde, öteki berikinde yitip yok olmaksızın varlıklarını sürdürmektedirler. Çatışma değil, işbirliği konusu olmaktadırlar. İki olasılığın böyle bir ilişki içinde olmaları buna gereksinim duyulması nedeniyledir. Özellikle tümevarımsal açıklama ve öngörme yordamlarında iki olasılığın varlığına da gereksinim duyulduğu için iki olasılık arasında çatışma değil de işbirliği kaçınılmaz olmaktadır. $\mathrm{Bu}$ da Janus yüzlü olasılık tamlamasının yeni dönemdeki matematikçilerce ve filozoflarca içten gelen bir onama duygusuyla benimsenmesini kolaylaştırdığı gibi, onu bilimin gözde bir tamlamasına da dönüştürmektedir.

\section{KAYNAKÇA}

Arntzenius, F ve Hall, N. (2003). On What We Know About Chance. British Journal of Philosophical Science, 54(2), 171-179.

Carnap, R. (1945). The two concepts of probability. Philosophy and Phenomenological Research, 5(4), 513-532.

Chaitin, G. (1975). Randomness and mathematical proof. Scientific American, 232, 47-52.

Cooper, N. (1965). The concept of probability. The British Journal for the Philosophy of Science, 16 (63), 226-238.

Çalışkan, M. A. (2018). Rastlantı. İstanbul: Küre Yayınları.

Daston, L. (1994). How probabilities came to be objective and subjective. Historia Mathematica, 21, 330-344.

Eagle, A. (2005). Randomness is unpredictability. The British Journal for the Philosophy of Science, 56(4), 749-790.

Fiş, R. (1995). Ben de halimce Bedreddinem. M. Beyhan (Çev.). İstanbul: Yön Yayıncılık.

Galavotti, M. C. (2005). Philosophical introduction of probability. Stanford: CSLI Publications. 
Gillies, D. (2000). Philosophical theories of probability. London: Routledge.

Hacking, I. (1991). The emergence of probability. Cambridge: Cambridge University Press.

Hempel, C. G. (1965). Aspects of scientific explanation and other essays in the philosophy of science. Toronto: Collier-Macmillan.

Hempel, C. G. ve Oppenheim, P. (1948). Studies in the logic of explanation. Philosophy of Science, 15(2), 135-175.

Herakleitos (2003). Kırık taşlar. E. Alova (Çev.). İstanbul: Bordo Siyah Yayınevi.

Herakleitos (2005). Fragmanlar. C. Çakmak (Çev.). İstanbul: Kabalcı Yayınevi.

Hume, D. (2017). İnsanın anlama yetisi üzerine bir soruşturma. F. B. Aydar (Çev.). İstanbul: İş Bankası Kültür Yayınları.

Humphreys, P. (1985). Why propensities cannot be probabilities? The Philosophical Review, 94(4), 557570.

Kitcher, P. ve Salmon, W. C. (1989). Scientific explanation. Minneapolis: University of Minnesota Press.

Kolmogorov, A. N. ve Uspensky, V. A. (1988). Algorithms and randomness. SIAM Theory of Probability and Applications, 32, 3.

Kyburg, H. E. (1972). Randomness. Proceedings of the Biennial Meeting of the Philosophy of Science Association, 1972, 137-149.

Laplace, M. de P. S. (2012). A philosophical essay on probabilities. London: John Wiley and Sons.

Levi, I. (1969). Are statistical hypotheses covering laws? Synthese, 20(3), 297-307.

Lewis, D. (1980). A subjectivist's guide to objective chance. R. C. Jeffrey, Studies in Inductive Logic and Probability II, Berkeley: University of California Press içinde. (s. 263-293).

Maher, P. (2010). Bayesian probability. Synthese, 172(1), 119-127.

Mittelstaedt, P. ve Weingartner, P. A. (2005). Laws of nature. Berlin: Springer-Verlag.

Nagel, E. (2013). Bilimin yapısı. A. Yardımlı (Çev.). İstanbul: İdea Yayınları.

Poincaré, H. (1912). Chance. The Monist, 22 (1), 31-52.

Popper, K. R. (1959). The propensity interpretation of probability. The British Journal for the Philosophy of Science, 10 (37), 25-42.

Ruelle, D. (1995). Rastlantı ve kaos. D. Yurtören (Çev.). Ankara: Tübitak Yayınları.

Salmon, W. C. (1989). Four decades of scientific explanation. Pittsburg: University of Pittsburg Press.

Savage, L. J. (1951). The theory of statistical decision. Journal of the American Statistical Association, 46 (253), 55-67.

Strevens, M. (1995). A closer look at the "new principle". The British Journal for the Philosophy of Science, 46, 545-561.

Strevens, M. (1999). Objective probability as a guide to the world. Philosophical Studies, 95(3), 243275.

Tağman, S. E. (2014). Bir söylem kümesi olarak açılamanın yöntembilimsel ve tarihsel temelleri üzerine bir araştırma. Yayınlanmış Doktora Tezi, Ankara Üniversitesi, Sosyal Bilimler Enstitüsü Felsefe Anabilim Dalı, Bilim Tarihi.

Thau, M. (1994). Undermining and admissibility. Mind, 103, 491-505.

Zabell, S. L. (2011). The subjective and the objective. Handbook of Philosophy of Statistics, 7, 11491174. 